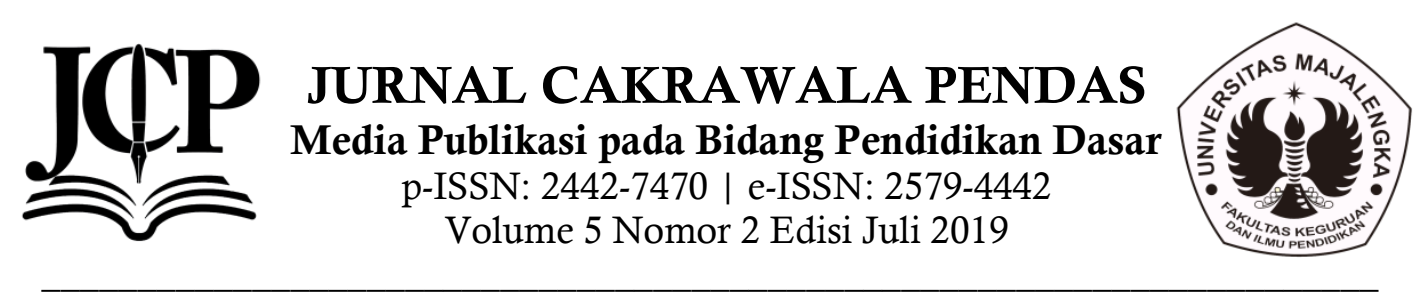

\title{
PENGEMBANGAN MEDIA KOMIK UNTUK MENINGKATKAN KOMPETENSI BERBAHASA PADA SISWA KELAS 3 SD
}

\author{
Nadia Astri Pandanwangi, Firosalia Kristin, Indri Anugraheni \\ Program Studi FKIP-PGSD, Universitas Kristen Satya wacana Salatiga, \\ 292014054@student.uksw.edu, firosalia.kristin@uksw.edu,indri.anugraheni@uksw.edu
}

\begin{abstract}
Abstrak
Media komik ini bertujuan untuk mengembangkan kompetensi berbahasa siswa pada pembelajaran Bahasa Indonesia kelas 3 SD. Penelitian ini menggunakan jenis penelitian Researchand Development ( $\mathrm{R} \& \mathrm{D})$ yang menggunakan model pengembangan ADDIE. Pengembangan dengan model ADDIE melalui beberapa tahapan diantaranya Analysis, Design, Development, Implementation, dan Evaluation. Subjek penelitian siswa kelas 3 dengan jumlah 20 orang. Teknik pengumpulan data berupa validasi dari ahli media dan materi. Hasil dari penelitian menunjukan bahwa media komik yang dihasilkan: (1) kevalitan data yang diperleh dari penilaian ahli media $85 \%$ dan dari ahli materi 90\% yang masuk dalam kategori sangat baik. (2) Respon dari angket guru dan siswa terhadap penggunaan media komik juga masuk dalam kategori yang sangat baik, perolehan angket guru adalah $90 \%$ dan angket respon siswa memperoleh skor $89.5 \%$. (3) hasil observasi kompetesi berbahasa siswa mengalami peningkatan dari sebelum menggunakan media komik hanya $48.5 \%$ dan setelah menggunakan media komik menjadi $71.25 \%$, artinya kompetensi berbahasa siswa meningkat $22.75 \%$. Berdasarkan hasil validasi ahli materi, ahli media, angket respon guru dan siswa yang rata-rata menunjukan kategori baik, maka media komik Bahasa Indonesia yang dikembangkan layak digunakan untuk membantu siswa meningkatkan kompetensi berbahasanya.
\end{abstract}

Kata kunci: komik, kompetensi berbahasa siswa 


\section{Pendahuluan}

Mengubah cara berpikir manusia menjadi lebih maju dan selalu berkembang dapat dilakukan melalui pendidikan. Pemerintah harus memperhatikan dan memperbaikiki kualitas pendidikan di Indonesia, mengingat Indonesia sebagai salah satu negara yang berkembang. Kualitas pendidikan dapat diperbaikai dengan banyak cara yang digunakan. Cara yang dilakukan untuk memperbaiki kualitas pendidikan salah satunya dengan mengembangkan aspek dalam pendidikan yang berkaitan dengan penggunaan media pembelajaran siswa. Pengembangan media pembelajaran siswa yang dilakukan agar siswa dapat mengembangkan kompetensi pengetahuan, keterampilan dan sikap yang dimiliki siswa. Menurut Budiarti dan Haryanto (2016:234) media pembelajaran merupakan salah satu alat bantu yang digunakan untuk mencapai tujuan pembelajaran, yang merupakan sarana komunikasi baik berupa media cetak maupun dengar. Media pembelajaran mempermudah siswa untuk untuk melihat hal yang sama dengan siswa laian melelui penjelasan guru. Penggunaan media merupakan faktor penting dalam kegiatan pembelajaran, penerapan media pembelajaran dimaksudkan agar belajar menjadi efektif, efisien,cepat, luas, banyak, dan bermakna bagi siswa.

$$
\text { Media pendidikan yang }
$$

dikembangkan hususnya pada jenjang SD salah satunya dalam mata pelajaran Bahasa Indonesia yang bertujuan untuk meningkatkan kompetensi berbahasa siswa. Disampaikan oleh Budiarti dan Haryanto (2016:234) pembelajaran Bahasa Indonesia di SD dapat membantu siswa mengenal dirinya, budayanya dan budaya orang laian, melalui bahasa siswa dapat mengemukakan gagasan dan perasaan dengan menggunakan kemampuan imajenatif yang dimilikinya. Definisi kompetensi menurut (PP No 74 tahun 2008) adalah seperangat pengetahuan, keterampilan, dan perilaku yang harus dimiliki, dihayati, dikuasai, dan diaktualisasi oleh siswa dalam pembelajaran. Salah satu kompetensi yang perlu dikembangkan dan ditekankan terutama di Sekolah Dasar adalah kompetensi berbahasa. Kompetensi berbahasa menurut Tarigan (2008:2) membagi kompetensi berbahsa menjadi empat keterampilan yaitu : keterampilan menyimak (listening skills), keterampilan berbicara (speaking skills), keterampilan membaca (reading skills), dan keterampilan menulis (writing skills) yang merupakan satu kesatuan yang saling terkait disebut catur tunggal. Halimah (2008:10) menyatakan standar kompetensi yang harus dicapai siswa melalui pembelajaran Bahasa Indonesia adalah untuk meningkatkan kompetensi siswa dalam berkomunikasi baik secara lisan maupun tulisan, menimbulkan penghargaan terhadap hasil karya manusia. Standar kompetensi tersebut dimaksudkan agar siswa dapat sisap menghadapi situasi multiglobal lokal yang berorientasi pada masa depan. Guru dapat membantu siswa membangun strategi komunikasi untuk menghadapi situasi kritis yang dihadapi siswa dengan cara memanfaatkan lingkungan sebagai sumber belajar dalam pebelajaran Bahasa Indonesia. Halijah (2017:326) aspek yang digunakan untuk meningkatkan kompetensi berbahasa siswa yang baik dan benar dengan menguasai banyak kosa kata, penguasaan kosa kata dalam pembelajaran Bahasa Indonesia mutlak harus ditingkatkan dalam proses belajar mengajar sehingga siswa dapat mengembangkan kemampuan dan keterampilan berbahasa (menyimak, berbicara, membaca dan menulis).

Hasil wawancara dan observasi yang dlakukan di SD Negeri Langensari 02, Kecamatan Ungaran Barat, Kabupaten Semarang ditemukan beberapa permasalan yang dihadapi guru dalam proses pembelajaran dalam mata pelajaran Bahasa Indonesia, yang menunjukkan: (1) guru kurang memiliki media belajar yang beragam untuk menyampaikan materi pelajaran khususnya pada mata pelajaran Bahasa Indonesia.(2) sekolah membutuhkan media berupa buku cerita yang sangat dibutuhkan siswa untuk mengembangkan imajinasinya.(3) guru belum mimiliki alat yang efektif sebagai media pembelajaran yang menyenangkan bagi siswa.(4) buku pelajaran siswa kurang memberikan materi yang menarik untuk tercapainya kompetensi berbahasa siswa. 
Permasalahan yang muncul dalam penelitian ini sejalan dengan penelitian yang dilakuakn oleh Listiyawati (2012:62) yang menyatakan bahwa dalam pembuatan perangkat pembelajaran yang digunakan dalam kegiatan pembelajaran guru mengalami kesulitan. Penelitian yang dilakukan oleh Sundari, dkk (2018:272) menyatakan bahwa buku cetak siswa yang digunakan dalam kegiatan pembelajaran kurang memberikan materi yang kurang menarik bagi siswa. Berdasarkan beberapa hasil penelitian lain dan observasi di lapangan maka dilakuakn pengembangan media pembelajaran berupa komik pendidikan yang digunakan dalam mata pelajaran Bahasa Indonesia untuk kelas 3 pada kurikulum KTSP untuk meningkatkan kompetensi berbahasa siswa. Permaslahan lain yang muncul relevan dengan penelitian yang dilakukan Zulaeha (2013:98) model pembelajaran Bahasa Indonesia yamg meliputi aspek membaca, menulis, menyimak dan berbicara cenderung monokultural dalam pelaksanaan dan penyajiannya, dalam buku pelajaran lebih mengankat budaya dari satu daerah tertentu, dan dalam pelaksanaannya belum menggunakan pendekatan dan metode tertentu yang dapat menggali potensi budaya yang dimiliki siswa.

Media merupakan bahasa latin dari kata jamak medium yang berarti perantara atau pengantar secara harafiah. Medeo adalah perantara atau pengantar pesan dari pengirim ke penerima pesan. Gagne (1970) menyatakan bahwa media adalah berbagai jenis komponen dalam lingkungan siswa yang dapat merangsangnya untuk belajar. Sementara Briggs (1970) berpendapat media adalah segala alat fisik yang dapat menyajikan pesan serta merangsang siswa untuk belajar. Relevan dengan penelitian yang dilakuakan oleh Anugraheni (2018: 134) Perangkat adalah alat/media yang digunakan untuk mencapai satu tujauan atau hasil yang diharapkan. Perangkat pembelajaran dapat diartikan sebagai alat yang digunakan oleh pendidik dalam melaksanakan proses kegiatan pembelajaran sehingga tercapai interaksi antara guru dan siswa. Interaksi antara guru dan siswa tertuang dalam kegiatan pembelajaran. Anugraheni, Kristin, dkk
(2018:35) menyatakan perangkat pembelajaran yang dihasilkan harus sesuai dengan tingkat kemampuan peserta didik, perangkat pembelajaran yang disusun dan dirancang berguna untuk proses kegiatan belajar mengajar yang dilakukan oleh guru. Dari penjelasan mengeni perangkat atau media pembelajaran dan melihat hasil obserfasi di lapangan maka yang dikembangkan pada penelitian ini adalah media komik untuk pembelajaran Bahasa Indonesia.

Komik merupakan salah satu media belajar dalam bentuk seni rupa dua dimensi yang menggunakan gambar-gambar tidak bergerak yang disususn sedemikian rupa sehingga membentuk jalinan cerita. Komik biasanya dicetak di atas media berupa kertas yang dilengkapi dengan teks berisi sebuah cerita. Menurut KBBI, komik adalah cerita bergambar (di majalah, surat kabar, atau bentuk buku) yang umumnya mudah dicerna dan lucu. Mc. Cloud (2002) mengemukakan bahwa gambar-gambar yang berurutan merupakan sarana komunikasi yang unggul. Hidayah (2017:37) komik adalah satu kartun yang mengungkapkan satu karakter yang memerankan satu cerita dalam urutan yang erat, dihubunkan dengan gambar untuk memberikan hiburan bagi pembaca, digunakan sebagai sumber belajar siswa untuk meningkatkan motivasi dan hasil belajar siswa. Menurut Hurlock (1978) komik merupakan media yang dapat dipergunakan untuk mengembangkan kepribadian anak, komikpun dapat dipergunakan sebagai sarana komunikasi, menyampaikan cerita, pesan, dan bahkan sampai pada hal-hal yang berbau ilmiah. Indaryari dan Jailani (2015:87) menyatakan media komik berpotensi lebih disukai siswa dikarenakan gambar dalam komik dapat menghidupkan deretan teks dan tulisan yang menyertainya, sehingga lebih mudah dipahami dan diingat. Siswa dapat membayankan terlebih dahulu apa yang menjadi topik inti yang dipelajari melalui gambar. Budiarti dan Haryanto (2016:235) media komik berfunsi sebagai penyampai pesan yang dikemas dalam bentuk yang menarik agar siswa lebih tertarik untuk belajar, tahap pembuatan media komik meliputi: (1) tahap pengidentifikasian 
target, (2) pengidentifikasian warna, dan (3) pembuatan sekenario. Pengembangan media komik dalam kegiatan belajar mengajar di SD bertujuan untuk memberikan inovasi dalam memperkaya media pembelajaran. Komik pembelajaran ini berisi gambar khas yang berurutan dilengkapi dengan panduan kata-kata yang dibuat semenarik mungkin untuk meningkatkan motivasi siswa dan minat siswa untuk belajar Bahas Indonesia.

Penelitian pengembangan media komik ini dapat membatu siswa dalam mengembangkan kompetensi berbahasanya di sekolah melalui proses pembelajaran oleh guru, dimana keterampilan berbahasa siswa akan tampak secara langsung dalam kegiatan komunikasinya sehari-hari. Dapat diperkuat melalui hasil penelitian oleh Ambaryani dan Airlanda (2017: 19) di SD Negeri Ngagrong, Ampel yang membuktikan bahwa melalui media komik siswa dapat meningkatkan hasil belajarnya. Hal ini membuktikan bahwa pengembangan media komik dapat membatu siswa dan guru dalam proses pembelajaran di sekolah.

\section{Metode Penelitian}

Model penelitian yang digunakan adalah Reaseacrch and Development (R \& D). Jenis pengembangan yang digunakan adalah procedural desain pembelajaran dari ADDIE (Pribadi,2011:25) yang terdiri dari tahap Analysis, Design, Development, Implementation, dan Evaluation, dimana data yang diperoleh berupa data kuantitatif yang didapatkan melalui angket. Menurut Sugiyono (2013) mendefinisikan metode penelitian pada dasarnya adalah cara ilmiah untuk mendapatkan data yang valid dengan tujuan dan kegunaan tertentu. Data yang didapat kemudian akan diolah dan dianalisis secara deskriptif-kuantitatif. Hasil validasi layak atau tidaknya penggunaan media komik dari angket ahli media, ahli materi, guru dan siswa terhadap penggunaan media komik kemudian dikonversi ke dalam skala Likert.

Tabel 1. Interpretasi Skor pada model ratingscale (Sugiyono, 2013: 170)

\begin{tabular}{cc}
\hline Presentase & Interpretasi \\
\hline $0 \%-25 \%$ & Sangat Tidak Baik \\
\hline
\end{tabular}

\begin{tabular}{cl}
\hline $26 \%-50 \%$ & Tidak Baik \\
\hline $51 \%-75 \%$ & Cukup Baik \\
\hline $76 \%-100 \%$ & Sangat Baik \\
\hline
\end{tabular}

Penelitian dilaksanakan pada 13-14 Maret 2019 di kelas 3 SD N Langensari 02 dengan subjek penelitian siswa kelas 3 yang berjumlah 20 orang. Penelitian ini selain untuk mengetahui respon siswa terhadap penggunaan media komik juga untuk mengetahui peningkatan kemampuan kompetensi berbahasa siswa sebelum dan sesudah menggunakan media komik. Peningkatan kemampuan kompetensi berbahasa siswa diukur melalui lembar observasi kompetensi berbahasa siswa.

\section{Hasil dan Pembahasan}

Penelitian pengembangan ini menghasilkan produk berupa komik "Buah Kejujuran" untuk siswa kelas 3 SD untuk pembelajaran Bahasa Indonesia. Pengembangan ini dilakukan dengan model ADDIE diantaranya :

Analisis (Analysis)

Berdasarkan penjelasan yang diperoleh, hasil analisis kebutuhan berkaitan dengan penggunaan media pembelajaran lain yang dapat digunakan dalam pembelajaran Bahasa Indonesia di SD. Berdasarkan hasil penelitian dan wawancara guru di sekolah, membuktikan bahwa penggunaan media pembelajaran khususnya komik masih jarang digunakan. Selain itu media yang digunakan siswa untuk meningkatkan kompetensi berbahasanya juga masih dianggap kurang.

\section{Analisis Kurikulum dan Materi}

Analisis yang dilakukan selanjutnya sesuai dengan analisis yang ada dalam kurikulum 2006 Bahasa Indonesia untuk kelas 3 SD semester genap dengan beberapa Standar Kompetensi (SK) dalam aspek mendengarkan, berbicara, membaca, dan menulis. Diturunkan menjadi satu Kompetensi Dasar (KD) dalam setiap aspek yang ada. Media pembelajaran komik yang disusun dari aspek mendengarkan, berbicara, membaca, dan menulis dapat diperoleh indikator berdasarkan materi yaitu : (1) Menirukan dialog yang ada dalam komik, (2) Menceritakan peristiwa/ permainan yang ada dalam komik, (3) 
Menjawab pertanyaan yang ada dalam bacaan komik, (4) Menuliskan kembali isi cerita dalam komik dengan bahasa sendiri. Tahap Pengembangan (Development)

Dalam tahap pengembangan produk berupa media komik Bahasa Indonesia "Buah Kejujuran" dapat diuraikan komponen yang ada dalam media komik sebagai berikut.

\section{Tampilan Cover}

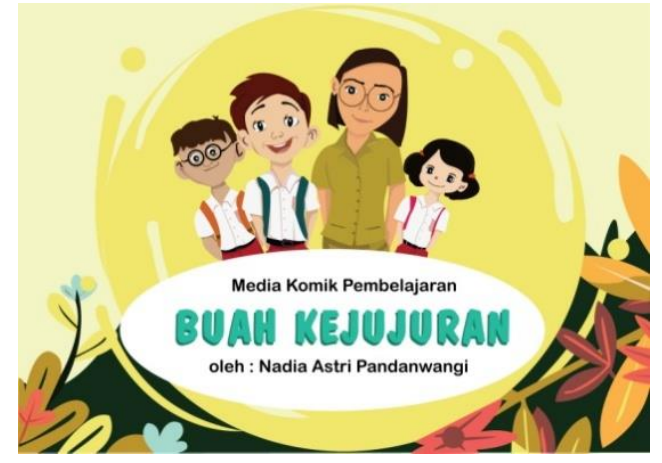

2. Tampilan SK, KD dan Indikator Komik

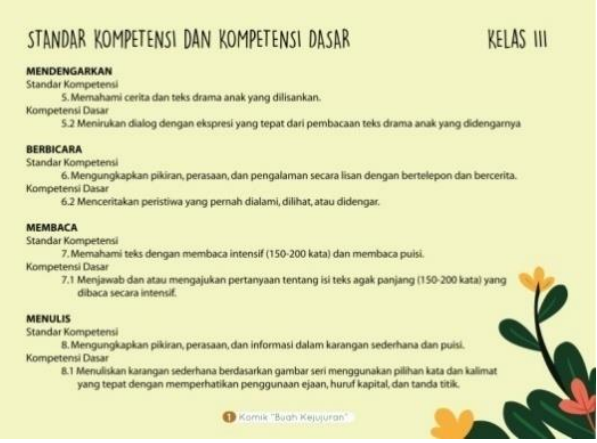

3. Tampilan Pedoman Penggunaan Komik

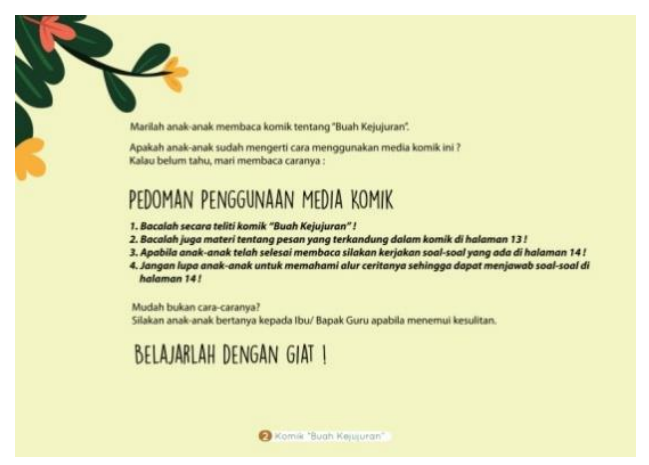

4. Tampilan pengenalan Tokoh

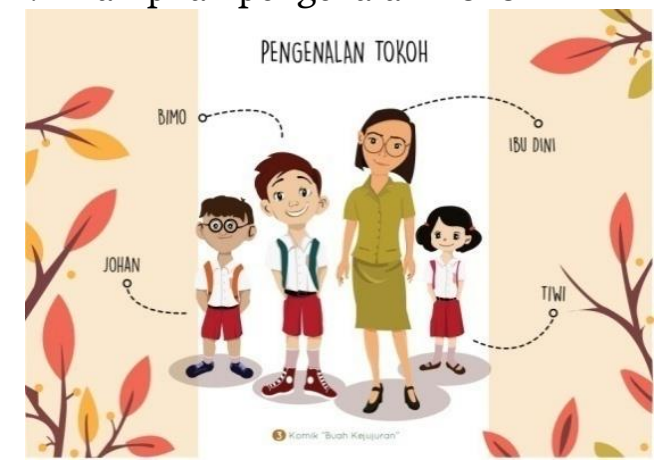

5. Tampilan Pesan dalam Komik

PESAN YANG ADA DI DALAM CERITA

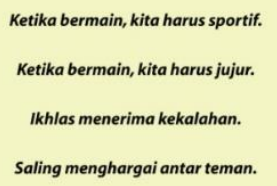

Saling menghargai antar teman.

(9)

6. Tampilan Kegiatan Latihan Soal

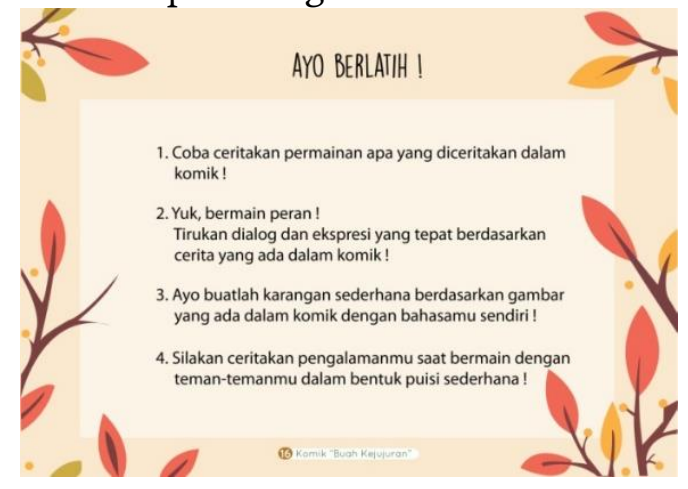

Tahap Implementasi

Tahap hasil validasi ahli media dan materi dilakuakn oleh dosen dari Universitas Kristen Satya Wacana (UKSW) sebagai pakar ahli media dan materi.

Tabel 2. Hasil Validasi Ahli Media

\begin{tabular}{llcc}
\hline No & Aspek Penilaian & Skor & $\begin{array}{c}\text { Skor Rata- } \\
\text { rata }\end{array}$ \\
\hline 1 & Tampilan & 20 & 3.33 \\
\hline 2 & Bahan & 8 & 4 \\
\hline 3 & Pembelajaran & 6 & 3 \\
\hline Total skor & \multicolumn{2}{c}{34} \\
\hline
\end{tabular}

Berdasar penilaian validasi ahli media dapat diperoleh hasil dari aspek 
penelian tampilan 20 dengan skor rata-rata 3.33. Penelian dalam aspek bahan diperoleh penilian 8 dengan skor rata-rata 4 . Dalam aspek pembelajaran diperoleh penilaian 6 dengan skor rata-rata 3 . Kesimpulan hasil penilaian keseluruhan aspek adalah 34 dengan rata-rata $85 \%$ penilaian dari ahli media ini bila dilihat dari intepretasi skor model ratingscale masuk dalam kategori sangat baik. Berdasarkan hasil penilaian ahli media produk media komik yang dikembangkan layak untuk diuji coba lapangan, namum berdasarkan saran dan masukan dari ahli media mengenai beberapa aspek media yang kurang dalam komik maka dilakukan revisi media komik sebelum diuji cobakan di lapangan.

Tabel 3. Hasil Validasi Ahli Materi

\begin{tabular}{llcc}
\hline No & $\begin{array}{c}\text { Aspek } \\
\text { Penilaian }\end{array}$ & Skor & $\begin{array}{c}\text { Skor Rata- } \\
\text { rata }\end{array}$ \\
\hline 1 & Pembelajaran & 22 & 3.66 \\
\hline 2 & Isi/materi & 14 & 3.5 \\
\hline Total skor & \multicolumn{2}{c}{36} \\
\hline
\end{tabular}

Berdasar penilaian validasi ahli materi maka dapat diperoleh hasil dari aspek penelian pembelajaran 22 dengan skor rata-rata 3.66. Penelian dalam aspek isi atau materi diperoleh penilian 14 dengan skor rata-rata 3.5. Kesimpulan hasil penilaian keseluruhan yang dilakukan oleh ahli media dari semua aspek adalah 36 dengan rata-rata $90 \%$ penilaian ini masuk dalam kategori sangat baik bila dilihat dari intepretasi skor model ratingscale. Dapat disimpulkan bahwa produk media komik yang dikembangkan layak untuk diuji cobakan, namun berdasarkan saran dan masukan dari ahli materi mengenai beberapa kekurangan dalam aspek materi di dalam komik maka perlu adanya revisi sebelum komik diujicoba lapangan.

Tabel 4. Hasil Angket Respon Guru

\begin{tabular}{llcc}
\hline No & Aspek Penilaian & Skor & Skor Rata-rata \\
\hline 1 & Pembelajaran & 15 & 3.75 \\
\hline 2 & Isi/materi & 11 & 3.66 \\
\hline 3 & Bahasa & 10 & 3.33 \\
\hline Total skor & \multicolumn{2}{c}{36} \\
\hline
\end{tabular}

Berdasarkan penilaian angket guru maka dapat diperoleh penilaian dari aspek pembelajaran adalah 15 dengan skor ratarata 3.75, dari aspek isi/materi diperoleh penilaian 11 dengan rata-rata skor 3.66 , dan pada aspek bahasa diperoleh penilaian 10 dengan skor rata-rata 3.33. kesimpulan dari penilaian keseluruhan aspek adalah 36 dengan rata-rata nilai $90 \%$, penilaian ini masuk dalam kategori sangat baik sehingga media komik layak untuk di uji cobakan ke siswa kelas III karena sesuai dengan kebutuhan siswa dalam khususnya pembelajaran Bahasa Indonesia. Sesuai dengan pendapat Sudjana Rivai (2013:69) sebagai media pembelajaran komik dapat digunakan guru secara efektif untuk meningkatkan minat, perbendaharaan kata, keterampilan membaca siswa.

Tabel 5. Hasil Angket Respon Siswa

\begin{tabular}{|c|c|c|c|c|}
\hline No & Aspek & Indikator & $\begin{array}{l}\text { No } \\
\text { Butir }\end{array}$ & $\begin{array}{c}\text { Jml Rata- } \\
\text { rata }\end{array}$ \\
\hline \multirow[t]{2}{*}{1} & \multirow[t]{2}{*}{ Media } & $\begin{array}{l}\text { Kesederhanaan } \\
\text { bahasa }\end{array}$ & 3 & \multirow{2}{*}{3.72} \\
\hline & & $\begin{array}{l}\text { Kejelasan } \\
\text { kalimat }\end{array}$ & 10 & \\
\hline \multirow[t]{2}{*}{2} & \multirow[t]{2}{*}{ Materi } & $\begin{array}{l}\text { Kesesuan } \\
\text { tampilan } \\
\text { penyajian }\end{array}$ & $\begin{array}{c}1,6 \\
7\end{array}$ & \multirow{2}{*}{3.75} \\
\hline & & $\begin{array}{l}\text { Kesesuaian } \\
\text { materi dengan } \\
\text { media }\end{array}$ & 2 & \\
\hline \multirow[t]{2}{*}{3} & \multirow[t]{2}{*}{$\begin{array}{l}\text { Isi } \\
\text { Cerita }\end{array}$} & $\begin{array}{l}\text { Perhatian } \\
\text { terhadap isi } \\
\text { media komik }\end{array}$ & 4,5 & \multirow{2}{*}{-3.76} \\
\hline & & $\begin{array}{l}\text { Kemudahan } \\
\text { memahami isi } \\
\text { cerita }\end{array}$ & 8,9 & \\
\hline \multicolumn{2}{|c|}{ Total Skor } & & & 750 \\
\hline
\end{tabular}

Hasil validasi angket siswa dalam uji coba lapangan dengan 20 siswa sebagai responden diperoleh penilaian pada aspek media dengan jumlah 149 dengan rata-rata skor 3.72 , penilaian dalam aspek materi diperoleh jumlah 300 dengan rata-rata skor 3.75, dan penilaian dalam aspek isi cerita diperoleh jumlah 301 dengan skor rata-rata 3.76. Kesimpulan hasil validasi respon siswa dalam uji coba lapangan terhadap penggunaan media komik memperoleh total skor keseluruhan 750 dengan rata-rata penilaian $93,7 \%$ yang masuk dalam kategori sangat baik, hal ini menunjukan bahwa seluruh siswa merespon baik terhadap penggunaan media komik dalam pembelajaran Bahasa Indonesia. Menurut 
Sudjana Rivai (2002:69) menyatakan bahwa komik sebagai sumber belajar harus didesain berisi materi-materi keilmuan yang mampu menumbuhkan minat baca siswa yang tadinya rendah. Hal tersebut disebabkan komik pendidikan mengandung gambar-gambar, ilustrasi berwarna, alur cerita yang ringkas, dan perwatakan yang realistis sehingga lebih menarik minat siswa untuk membaca.

Tahap hasil observasi peningkatan kompetensi berbahasa siswa sebelum dan sesudah menggunakan media komik. Hasil observasi ini untuk mengetahui hasil perbandingan kemampun kompetensi berbahasa siswa sebelum dan sesudah penggunaan media komik, observasi ini dilakukan dengan 20 siswa sebagai responden. Berikut tabelhasil perbandingan kompetensi siwa sebelum dan sesudah menggunakan media komik yang terbagi dalam empat aspek membaca, menulis, mendengarkan dan berbicara.

Tabel 6. Hasil Observasi Siswa Sebelum

\begin{tabular}{|c|c|c|c|c|c|c|c|c|c|c|}
\hline & \multicolumn{10}{|c|}{ Penggunaan Media Komik } \\
\hline \multirow{3}{*}{ Responden } & \multicolumn{7}{|c|}{ Kompetensi Kompetensi Kompetensi } & \multicolumn{3}{|c|}{$\begin{array}{c}\text { Kompetensi } \\
\text { Berbicara }\end{array}$} \\
\hline & \multicolumn{2}{|c|}{ Indikator } & \multicolumn{2}{|c|}{ Indikator } & \multicolumn{3}{|c|}{ Indikator } & \multicolumn{3}{|c|}{ Indikator } \\
\hline & A $\mathrm{B}$ & $\mathrm{C}$ & $\mathrm{A}$ & $\mathrm{B}$ & C A & $\mathrm{B}$ & $\mathrm{C}$ & A & $\mathrm{B}$ & C \\
\hline $\begin{array}{l}\text { Jum } \\
\text { Resp }\end{array}$ & $45 \quad 40$ & 40 & 38 & 38 & $34 \quad 34$ & 42 & 37 & 43 & 38 & 38 \\
\hline \multirow{2}{*}{ Rata-rata } & $2.25 \quad 2$ & 2 & 1.9 & 1.9 & 1.71 .7 & 2.1 & 1.9 & 2.1 & 1.9 & 1.9 \\
\hline & \multicolumn{2}{|l|}{ 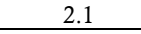 } & \multicolumn{2}{|r|}{1.8} & & \multicolumn{2}{|l|}{1.9} & \multicolumn{3}{|c|}{2} \\
\hline$\%$ & \multicolumn{2}{|c|}{$52.5 \%$} & \multicolumn{2}{|c|}{$45 \%$} & \multicolumn{3}{|c|}{$47.5 \%$} & \multicolumn{3}{|c|}{$50 \%$} \\
\hline
\end{tabular}

Hasil observasi siswa sebelum menggunakan media komik diperoleh hanya $52.5 \%$ dalam aspek kompetensi berbahasa siswa, artinya hanya sekitar 10 siswa yang kompetensi berbahasanya baik. Dalam aspek kompetensi menulis diperoleh $45 \%$, artinya bila dirata-rata hanya 9 siswa dari 20 siswa yang kompetensi menulisnya baik. Diperoleh hasil $47.5 \%$ dari aspek kompetensi menyimak sebelum menggunakan media komik, artinya hanya bila dirata-rata hanya 9 siswa yang memiliki kompetensi menyimak baik. Terakhir dalam aspek kompetensi berbicara diperoleh hasil $50 \%$, artinya rata-rata hanay 10 siswa dari 20 siswa yang memiliki kompetensi berbicara yang baik.
Tabel 7. Hasil Observasi Siswa Setelah Penggunaan Media Komik

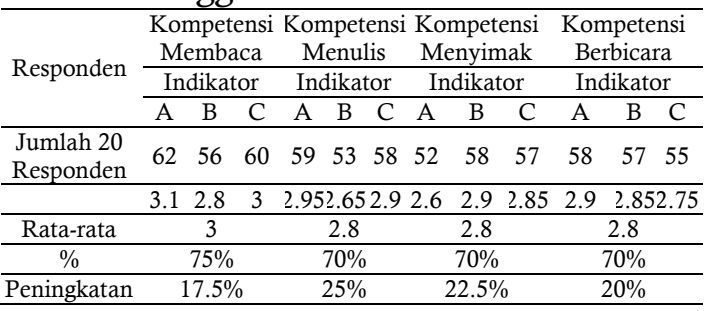

Peningkatan aspek kompetensi membaca meningkat sebesar $17.5 \%$, diperoleh dari hasil sebelum menggunakan media komik adalah $52.5 \%$ sedangkan hasil setelah menggunakan media komik adalah $75 \%$. Peningkat aspek kompetensi menulis mencapai 25\%, dimana sebelum menggunakan media komik hasil yang diperoleh adalah $45 \%$ sedang hasil setelah menggunakan media komik menjadi $70 \%$. Dalam aspek kompetensi menyimak meningkat $22.5 \%$, sebelum menggunakan media komik diperoleh hasil $47.5 \%$ sedang setelah menggunakan media komik meningkat menjadi 70\%. Peningkatan terakhir terdapat dalam aspek kompetensi berbicara mencapai $20 \%$ dimana sebelum menggunakan media komik diperoleh hasil $50 \%$ namun setelah menggunakan media komik hasil yang diperoleh adalah $70 \%$. Dapat diperoleh rata-rata hasil observasi siswa sebelum menggunakan media komik adalah $48 \%$ dan sesudah menggunakan media komik adalah $71.25 \%$, sehingga disimpulkan bahwa media komik yang dikembangkan dapat meningkatkan kompetensi berbahasa yang dimiki oleh siswa sebesar $22.75 \%$. Berdasarka pendapat dari Daryanto (2010:139-140) komik dapat menambah kemampuan membaca siswa serta penguasaan kosakata yang jauh lebih banyak dari pada siswa yang tidak menyukai komik. Maka dengan adanya kecenderungan inilah komik dibuat dengan berisikan materi pelajaran agar siswa lebih suka untuk membaca dan belajar. Dibandingkan dengan penggunaan media buku teks yang tidak bergambar serta tidak mengandung ilustrasi yang menarik, komik diharapkan dapat membangkitkan minat siswa untuk lebih rajin belajar sehingga hasil belajarnya dapat meningkat. Diperkuat melalui penelitian yang dilakukan oleh Budiarti dan Haryanto (2016) yang menyatakan bahwa media 
komik dapat meningkatkan daya ingat karena siswa belajar dengan cara yang menyenangkan melalui cara mereka sendiri dengan imajenasi yang diarahkan dari pemberian materi yang ada di dalam komik. Hal ini membuktikan bahwa melalui media komik siswa dapat meningkatkan motivasi belajar dan keterampilan berbahasanya.

\section{Kesimpulan}

Menurut hasil penelitian dan pembahasan yang telah dilakukan, maka dapat diperoleh simpulan terhadap media komik Bahasa Indonesia "Buah Kejujuran" sebagai berikut: (1) Media komik pembelajaran Bahasa Indonesia "Buah Kejujuran" dapat dikembangkan dengan model pengembangan ADDIE.

Efektifitas media komik pembelajaran Bahasa Indonesia "Buah Kejujuran" dapat diketahui dan dilihat dari hasil penelitian berikut. (3) Hasil dari validasi ahli media $85 \%$ dengan kategori sangat baik. Hasil validasi ahli materi 90\% dengan kategori sangat baik. (4) Hasil angket respon guru $90 \%$ dengan kategori sangat baik. Hasil angket respon siswa $89.5 \%$ dengan kategori sangat baik. (5) Hasil observasi kompetensi berbahasa siwa sebelum meggunakan media komik $48.5 \%$ dengan katgori cukup. Hasil observasi kompetensi berbahasa siswa setelah menggunakan media komik $71.25 \%$ dengan kategori baik. Peningkatan kompetensi berbahasa siswa sebelum dan sesudah menggunkan media komik adalah $22.75 \%$.

Berdasarkan penelitian yang dilakukan maka dapat diberikan saran sebagai berikut: Pengembangan media konik dapat dikembangkan lebih lanjut berkenaan dengan materi lain yang masih berkaitan dengan peningkatan kompetensi berbahasa siswa. Pengembangan media komik yang lain juga dapat dilakukan untuk pembelajaran yang lebih menarik bagi siswa.

\section{Daftar Pustaka}

Ambaryani ., \& Airlanda, G. S. (2017). Pengembangan Media Komik untuk Efektivitas dan Meningkatkan Hasil Belajar Kognitif Materi Perubahan Lingkungan Fisik.Jurnal Pendidikan Surya Edukasi, 3(1).
Anugraheni, I. (2018). Pengembangan Perangkat Pembelajaran Matematika Berbasis Pendidikan Karakter Kreatif Di Sekolah Dasar.Jurnal Refleksi Edukatika. $8(2)$.

Anugraheni, I., Kristin, F., \& Airlanda, G. S. (2018). Pengembangan Bahan Ajar Pembelajaran Berbasis Olah Pikir Di Sekolah Dasar. Jurnal Inventa, (2).

Budiarti, W. N., \& Haryanto. (2016). Pengembangan Media Komik Untuk Meningkatkan Motivasi Belajar Dan Keterampilan Membaca Pemahaman Siswa Kelas IV. Jurnal Prima Edukasia, 4(2).

Daryanto. (2010). Media Pembelajaran. Yogyakarta: Gava Media.

Gagne, Robert M \& Leslie J Briggs. (1970). Principles of Instructional Design. Harcort Brace Jovanivich Collage Publisher. San Diego.

Halijah. (2017). Meningkatkan Kemampuan Berbahasa Indonesia Dengan Menerapkan Model Pembelajaran Think Pair Share. Jurnal Global Edukasi, 1(3).

Halimah, L. (2008). Pemberdayaan Lingkungan Sebagai Sumber Belajar dalam Upaya Meningkatkan Kompetensi Berbahasa Indonesia Siswa Kelas 4 SD Laboratorium UPI Kampus Cibiru. Jurnal Pendidikan Dasar, (10).

Hidayah, N. (2017). Pengembangan Media Pembelajaran Berbasis Komik Pada Mata Pelajaran Ilmu Pengetahuan Sosial Kelas IV Mi Nurul Hidayah Roworejo Negerikaton Pesawaran. Jurnal Pendidikan dan Pembelajaran Dasar, 4(1).

Hurlock, E. B. (1978). Child Development (6th ed.). New York: McGrawHill. 
Indaryati., \& Jailani. (2015). Pengembangan Media Komik Pembelajaran Matematika Meningkatkan Motivasi Dan Prestasi Belajar Siswa Kelas $V$. Jurnal Prima Edukasia, 3(1).

Listyawati, M. (2012). Pengembangan Perangkat Pembelajaran IPA Terpadu di SMP. Jurnal of Innovative Science Education, 1(1).

Mc Cloud, scott. (2002). Understanding Comic. Jakarta. KPG.

Pribadi, B.A. (2011). Model Desain Sistem Pembelajaran. Jakarta :Dian Rakyat.

Sugiyono. 2013. Metode Penelitian Pendidikan: Pendekatan Kuantitatif, Kualitatif, dan $R \& D$. Bandung : Penerbit Alfabeta.

Sudjana, Nana., \& Ahmad. Rivai. (2002). Media Pembelajaran. Bandung: Sinar Baru Algesindo.

Sudjana, Nana., \& Ahmad. Rivai. (2013). Media Pembelajaran. Bandung: Sinar Baru Algesindo.

Sundari, Lilis, dkk. (2018). Pengembangan Multimedia Interaktif Menggunakan Adobe Flash CS3 Profesional untuk Meningkatkan Hasil Belajar IPS Kelas 4 SD. Jurnal Pendidikan Berkarakter, 1(1).

Tarigan, Henry Guntur. 2008. Berbicara Sebagai Suatu Keterampilan Berbahasa. Bandung :Angkasa.

Zulaeha, I. (2013). Pengembangan Model Pembelajaran Keterampilan Berbahasa Indonesia Berkonteks Multikultural. Jurnal Litera, 12(1). 